\title{
PERTANGGUNGJAWABAN BIDAN DALAM PEMBERIAN SUNTIKAN OKSITOSIN PADA IBU BERSALIN NORMAL DI BPS YANG MENGAKIBATKAN \\ PERDARAHAN MENURUT PASAL 23 UNDANG-UNDANG NOMOR 36 TAHUN 2009 TENTANG KESEHATAN
}

\author{
Oleh : Rissa Nuryuniarti, S.ST,.MH.Kes
}

\begin{abstract}
Indonesian Law No. 36 of 2009 on article 23 about Health according health personnel are authorized to organize health services. One midwife authority in making aid delivery by giving oxytocin injections were performed on the second stage of labor to increase contractions. So if she gives them injections of oxytocin before the second stage is an action that is not an authority. The use of oxytocin is one of them, used to induce or risk of oxytocin augmentation of labor at the time of delivery to the induction or augmentation (strengthening contractions) many events happening in the form of a tear of the uterus that can cause bleeding which can be fatal.

The problems that exist in the study related to the violation of the midwife that is giving an injection of oxytocin in normal birth mothers who cause bleeding postpartum. Need enforcement of such measures as the legal consequences, because a midwife already have the authority and standards of practice of midwives in this case to limit the authority in accordance with applicable regulations

The purpose of this study was to describe the authority of midwives perform an injection of oxytocin administration and accountability of midwives in the provision of an injection of oxytocin in normal birth mothers who cause bleeding. Framework in this study is rooted in the theory of legal state, injecting oxytocin administration theory, the theory of the concept of midwives and administrative sanctions.

The method used in this research is a normative juridical approach, further examined regulations on midwives authority and responsibility dihubungan by Law number 36 of 2009 on Health. Collecting data through interviews with the Indonesian Midwives Association Branch Ciamis. The analysis technique used is the method of normative analysis of qualitative and descriptive.

Results showed that administration of an injection of oxytocin in maternal an authority under Act No. 36 of 2009 Article 23, namely the injection of oxytocin in normal birth mother is the authority midwife who performed after the baby is born. Responsibility midwife in such cases is to provide compensation to patients both material and immaterial to the application of sanctions Article 1365 of the Civil Code which stipulates that any unlawful acts that bring harm to others, because it requires that the person who hurt replace those losses.
\end{abstract}

Keywords : Responsibility of Midwives, Oxytocin gift, Postpartum Hemorrhage 


\section{ABSTRAK}

Menurut Pasal 23 Undang-Undang Nomor 36 Tahun 2009 disebutkan bahwa tenaga kesehatan berwenang untuk menyelenggarakan pelayanan kesehatan. Salah satu kewenangan bidan dalam melakukan pertolongan persalinan yaitu dengan memberikan suntik oksitosin yang dilakukan pada kala II persalinan untuk meningkatkan kontraksi. Sehingga apabila bidan memberikan suntik oksitosin sebelum kala II merupakan tindakan yang bukan menjadi kewenangannya. Penggunaan oksitosin salah satunya, digunakan untuk menginduksi atau augmentasi persalinan risiko pemberian oksitosin pada waktu persalinan untuk melakukan induksi atau augmentasi (memperkuat kontraksi) banyak terjadi kejadian berupa robekan rahim sehingga dapat menyebabkan perdarahan yang bisa berakibat kematian.

Permasalahan yang ada dalam penelitian ini berkaitan dengan adanya pelanggaran bidan yakni pemberian suntikan oksitosin pada ibu bersalin normal yang mengakibatkan perdarahan postpartum. Perlu penegakkan dari tindakan tersebut sebagai akibat hukumnya, karena seorang bidan sudah mempunyai wewenang dan standar praktik bidan dalam hal ini guna membatasi wewenang sesuai dengan peraturan yang berlaku

Tujuan penelitian ini untuk memaparkan kewenangan bidan melakukan pemberian suntikan oksitosin dan pertanggungjawaban bidan dalam pemberian suntikan oksitosin pada ibu bersalin normal yang mengakibatkan perdarahan. Kerangka pemikiran dalam penelitian ini adalah bersumber pada teori negara hukum, teori pemberian suntik oksitosin, teori konsep bidan dan sanksi administrasi.

Metode yang digunakan pada penelitian ini adalah pendekatan yuridis normatif, selanjutnya dikaji peraturan tentang kewenangan bidan dan pertanggungjawabannya dihubungan dengan Undang-Undang nomor 36 tahun 2009 tentang Kesehatan. Pengumpulan data melalui wawancara langsung dengan Ikatan Bidan Indonesia Cabang Ciamis. Teknik analisis yang digunakan adalah metode analisis normatif kualitatif dan deskriptif.

Hasil penelitian diperoleh bahwa pemberian suntikan oksitosin pada ibu bersalin merupakan kewenangan bidan sesuai Undang-Undang Nomor 36 Tahun 2009 Pasal 23 yakni pemberian suntikan oksitosin pada ibu bersalin normal merupakan kewenangan bidan yang dilakukan setelah bayi lahir. Tanggungjawab bidan dalam kasus tersebut adalah dengan memberikan ganti rugi kepada pasien baik secara materil maupun immateri dengan penerapan sanksi Pasal 1365 KUHPerdata yang menentukan bahwa tiap perbuatan melanggar hukum yang membawa kerugian kepada orang lain, mewajibkan orang yang karena salahnya mengganti kerugian tersebut.

Kata Kunci : Tanggungjawab Bidan, Pemberian Oksitosin, Perdarahan Postpartum 


\section{Pendahuluan.}

Hak atas pelayanan dan perlindungan kesehatan bagi ibu dan anak merupakan hak dasar sebagaimana termaktub dalam Undang-undang Dasar 1945. Pasal 28 H UUD 1945 menentukan bahwa setiap orang hidup sejahtera lahir dan batin bertempat tinggal dan mendapat lingkungan hidup yang baik dan sehat serta berhak memperoleh pelayanan kesehatan. Pasal 34 ayat (3) UUD 1945 menentukan bawha negara bertanggung jawab atas penyediaan fasilitas pelayanan kesehatan dan fasilitas pelayanan umum yang layak.

Pencantuman hak terhadap pelayanan kesehatan tersebut, tidak lain bertujuan untuk menjamin hak-hak kesehatan yang fundamental seperti tertuang dalam Declaration of Human Right 1948, bahwa health is a fundamental human right. Selain itu terdapat juga serangkaian konvensi internasional yang ditandatangani oleh pemerintah Indonesia yaitu UU No. 7 Tahun 1984 tentang Ratifikasi Penghapusan segala bentuk diskriminasi terhadap perempuan, kesepakatan konvensi internasional tentang perempuan di Beijing tahun 1995. Adapun mengenai pembangunan kesehatan nasional yang diatur dalam Pasal 173 Undang-Undang No. 36 Tahun 2009 tentang Kesehatan. ${ }^{1}$

Sebagai salah satu negara yang ikut menandatangani Deklarasi Millennium Development Goals (MDGs), Indonesia mempunyai komitmen menjadikan program-program MDGs sebagai bagian yang tidak terpisahkan dari program pembangunan nasional baik dari jangka pendek maupun jangka menengah dan panjang. Termasuk dalam hal ini poin ke empat dan kelima

\footnotetext{
${ }^{1}$ Tedi Sudrajat dan Agus Mardiyanto, "Hak Atas Pelayanan dan Perlindungan Kesehatan Ibu dan Anak (Implementasi Kebijakan di Kabupaten Banyumas)", Jurnal Dinamika Hukum, Vol. 12 No. 2 Mei 2012, Purwokerto: Fakultas Hukum Universitas Jenderal Soedirman, hlm. 261-262
} 
dimana menurunkan angka kematian anak dan meningkatkan kesehatan maternal. ${ }^{2}$

Angka kematian ibu menunjukkan adanya kenaikan sehingga dalam perencanaan pembangunan nasional (Bappenas) bahwa Indonesia akan sulit mencapai target Millenium Develompment Goal's (MDGs) untuk menurunkan AKI sampai ke angka 102 pada tahun 2015. Bappenas memperkirakan bahwa pada tahun 2015, AKI di Indonesia masih akan berkisar di angka 163. Indonesia tertinggal jauh dari Malaysia dan Thailand yang angka AKI nya masing-masing 30 dan 24 kematian ${ }^{3}$.

Perdarahan pada bidang kebidanan tetap menjadi penyebab utama kematian ibu di negara berkembang, 10-30\% kematian langsung ibu di negara berkembang masih merupakan pertanyaan. Itu juga komponen utama morbiditas berat pada ibu. Angka kematian ibu dan bayi merupakan salah satu indikator derajat kesehatan di suatu negara. Menurut hasil Survey Demografi Kesehatan Indonesia (SDKI) tahun 2012 tingkat kematian ibu saat melahirkan masih tinggi, atau hampir setiap satu jam, dua ibu melahirkan meninggal dunia yaitu sebesar 359/100.000, sedangkan angka kematian bayi (AKB) mencapai 32 per 1000 kelahiran hidup. Kematian ini terjadi peningkatan bila dibandingkan dengan hasil SDKI pada tahun 2007 yakni 228/100.000 kelahiran hidup dan angka kematian bayi (AKB) sebesar 32 per 1.000 kelahiran hidup 4 .

Berbagai faktor penyebab AKI secara langsung diantaranya adalah perdarahan $25 \%$, sepsis $15 \%$, hipertensi dalam kehamilan $12 \%$, partus macet

\footnotetext{
${ }^{2}$ Emmy Latifah, "Harmonisasi Kebijakan Pengentasan Kemiskinan di Indonesia Yang Berorientasi Pada Millennium Development Goals", Jurnal Dinamika Hukum, Vol. 11 No. 3 2011, Purwokerto: Fakultas Hukum Universitas Jenderal Soedirman, hlm. 403

${ }^{3}$ Depkes RI, 2012. Pencapaian Target Millenium Develompment Goal's (MDGs)

${ }^{4}$ Depkes RI, 2012. Hasil Survei Demografi Kesehatan Indonesia 2012
} 
$8 \%$, komplikasi aborsi tidak aman $13 \%$, dan sebab lain $8 \%$. Sedangkan penyebab tidak langsung kematian ibu dan bayi adalah tiga terlambat. ${ }^{5}$

Hasil analisis data kematian ibu di Provinsi Jawa Barat pada tahun 2013 diketahui bahwa Ratio Kematian Ibu mencapai 86,27 per $100.000 \mathrm{KH}$ atau berkisar 781 Kasus, analisis penyebab kematian tersebut sebanyak 31,7\% diantaranya meninggal akibat perdarahan postpartum, sebanyak $29.3 \%$ diakibatkan hipertensi dan preeklampsia, 5.6\% disebabkan karena infeksi, sebanyak $0.6 \%$ diakibatkan karena partus lama. ${ }^{6}$

Berdasarkan data yang dimiliki Dinas Kesehatan Ciamis, angka kematian ibu menduduki peringkat pertama di Jawa Barat dengan jumlah kematian sebanyak 36 kasus pada tahun 2014. Penyebab tingginya kematian ibu tidak hanya pendarahan yang mencapai $40 \%$ yang dialami ketika persalinan, namun disebabkan pula oleh infeksi dan hipertensi.

Penggunaan oksitosin salah satunya, digunakan untuk menginduksi atau augmentasi persalinan. Meskipun jarang ada data tentang itu, pemberian oksitosin selama persalinan merupakan prosedur yang rutin di negara berkembang yang dilakukan di rumah sakit dengan fasilitas yang lengkap. Saat ini, yang berkembang bahwa penggunaan oksitosin banyak di salah gunakan yang dilakukan oleh bidan yang tidak mempunyai kewenangan. Seperti diketahui bahwa risiko pemberian oksitosin pada waktu persalinan untuk melakukan induksi atau augmentasi (memperkuat kontraksi) banyak terjadi kejadian berupa robekan rahim sehingga dapat menyebabkan perdarahan yang bisa berakibat kematian. $^{7}$

\footnotetext{
${ }^{5}$ Saifuddin, 2012. Ilmu Kebidanan dan Kandungan. Yayasan Bina Pustaka Sarwono Prawirohardjo. Jakarta.

${ }^{6}$ Dinas Kesehatan Provinsi Jawa Barat. Analisis Penyebab Kematian Ibu tahun 2013.

${ }^{7}$ Gomella TL, Cunningham MD, Eyal FG, Zenk KE. Neonatology, Management, procedures, on call problems disease and drugs. New York : Lange Books/Mc Graw-Hill, 2004; 247-50
} 
Secara farmakologi oksitosin digunakan untuk menginduksi atau augmentasi persalinan, namun memperbanyak reseptornya, dengan demikian dapat merusak mekanisme oksitosin dan akan memberikan efek rusaknya kontraktilitas uterus setelah persalinan dengan begitu meningkatkan resiko terjadinya atoni uteri yang mengakibatkan perdarahan postpartum.

Berdasarkan data yang diperoleh dari Dinas Kesehatan Kabupaten Ciamis dalam kurun waktu tahun 2012-2015 diperoleh fakta seputar perbuatan melawan hukum terhadap wewenang pelayanan Bidan Praktik Mandiri (BPM) di Kabupaten Ciamis. Sebagian kasus bukan wewenang bidan dalam melakukan praktiknya dan seharusnya dirujuk ke tingkat yang lebih tinggi untuk memperoleh pertolongan dan sesuai dengan wewenangnya atau tanggung jawabnya. ${ }^{8}$

Sebagai seorang tenaga kesehatan yang langsung memberikan pelayanan kesehatan kepada masyarakat, seorang bidan harus melakukan tindakan dalam praktik kebidanan secara etis, serta harus memiliki etika kebidanan yang sesuai dengan nilai-nilai keyakinan filosofi profesi dan masyarakat. Selain itu bidan juga berperan dalam memberikan persalinan yang aman, memastikan bahwa semua penolong persalinan mempunyai pengetahuan, keterampilan dan alat untuk memberikan pertolongan yang aman dan bersih. ${ }^{9}$

Berdasarkan hasil studi pendahuluan yang dilakukan pada bulan Juni tahun 2015 diperoleh data selama tahun 2014 Pengurus Daerah Ikatan Bidan Indonesia (PD IBI) Cabang Kabupaten Ciamis telah melakukan sidang kode etik kebidanan sebanyak 27 kasus. Sebanyak 9 dari kasus tersebut adalah terdapat bidan yang memberikan suntikan oskitosin pada ibu bersalin pada kala I persalinan yang dapat menyebabkan perdarahan postpartum.

\footnotetext{
${ }^{8}$ Hasil Wawancara dengan Pengurus IBI Kabupaten Ciamis. Pukul 10.30 WIB Hari Kamis, tanggal 9 Juli 2015

${ }^{9}$ Yanti dan W E Nurul, 2010, Etika Profesi Dan Hukum Kebidanan, Yogyakarta: Pustaka Rihama, hlm. 85
} 
Permenkes No.572/PER/Menkes/VI/96 yang memberikan wewenang dan perlindungan bagi bidan dalam melaksanakan tindakan penyelamatan jiwa ibu dan bayi baru lahir. Menurut Pasal 23 Undang-Undang Nomor 36 Tahun 2009 disebutkan bahwa tenaga kesehatan berwenang untuk menyelenggarakan pelayanan kesehatan. Namun dalam ayat ini dijelaskan bahwa kewenangan yang dimaksud dalam ayat ini adalah kewenangan yang diberikan berdasarkan pendidikannya setelah melalui proses registrasi dan pemberian izin dari pemerintah sesuai dengan peraturan perundang-undangan.

Salah satu kewenangan bidan dalam melakukan pertolongan persalinan yaitu dengan memberikan suntik oksitosin yang dilakukan pada kala II persalinan untuk meningkatkan kontraksi. Sehingga apabila bidan memberikan suntik oksitosin sebelum kala II merupakan tindakan yang bukan menjadi kewenangannya. Artinya tindakan tersebut bukan wewenang bidan dalam melakukan praktiknya dan seharusnya dokter spesialis obstetri dan ginekologi (dr. Sp.OG) yang memberikan oksitosin melalui infus pada ibu bersalin, hal ini dilakukan atas indikasi apabila ibu bersalin tidak mengalami kemajuan persalinan.

Aspek hukum dan keterkaitannya dengan praktek bidan didasarkan pada klien yang datang ke praktek bidan karena membutuhkan pertolongan. Atas dasar tersebut norma susila yang telah ada lebih dikuatkan dengan undangundang, yang mana apabila apa yang telah dilakukan bidan diduga ada kesalahan atau mengakibatkan cacat, maka terkena sanksi hukum baik perdata maupun pidana.

Oleh karena itu, pentingnya penelitian ini adalah dapat ditegakannya penegakan hukum terhadap pelanggaran bidan dan akibat hukumnya, karena 
seorang bidan sudah mempunyai wewenang dan standar praktik bidan dalam hal ini guna membatasi wewenang sesuai dengan peraturan yang berlaku. Bidan mengetahui dan dapat mengimplementasikan tanggung jawabnya sesuai dengan peraturan yang ada tanpa melampaui wewenang sesuai dengan kompetensinya. Dengan demikian, pelayanan kebidanan yang tidak sesuai dengan kewenangannya, maka akan mendapat konsekuensi hukum akan muncul tatkala terjadi penyimpangan kewenangan. ${ }^{10}$

Menurut Keputusan Menteri Kesehatan No 1464/MenKes/per/X/2010, Pasal 23 ayat (1) menentukan bahwa dalam rangka pelaksanaan pengawasan sebagaimana dimaksud dalam Pasal 21, Menteri, Pemerintah daerah provinsi dan pemerintah daerah kabupaten/ kota dapat memberian tindakan administratif kepada bidan yang melakukan pelanggaran terhadap ketentuan penyelenggaraan praktik dalam peraturan ini. Ayat (2) dari pasal tersebut menentukan bahwa tindakan administratif sebagaimana dimaksud pada ayat (1) dilakukan melalui teguran lisan, teguran tertulis, pencabutan SIKB/SIPB untuk sementara paling lama 1 tahun; atau pencabutan SIKB/SIPB selamanya. Dari sudut hukum, profesi tenaga kesehatan dapat diminta pertanggungjawaban berdasarkan hukum perdata, hukum pidana maupun hukum administrasi. ${ }^{11}$

Oleh karena itu setiap tenaga kesehatan harus memperhatikan standar yang berlaku di profesinya termasuk bidan, selain itu bidan juga harus patuh pada Kode Etik Kebidanan. Kode etik Kebidanan merupakan suatu pernyataan komprehensif profesi yang memberikan tuntunan bagi bidan untuk melaksanakan

\footnotetext{
${ }^{10}$ Iswandari, Dini Hargianti. “Aspek Hukum Penyelenggaran Praktik Kedokteran: Suatu Tinjauan Berdasarkan Undang-Undang No.9/2004 Tentang Praktik Kedokteran”. Jurnal Manajemen Pelayanan Kesehatan, Vol 09 No 2 Juni 2006. Universitas Gadjah Mada Pusat Manajemen Pelayanan Kesehatan

${ }^{11}$ H. J. J. Lenan dan P. A. F. Lamintang. 1991. Pelayanan Kesehatan dan Hukum : suatu studi Tentang Hukum Kesehatan. Bandung: Rineka Cipta. Hlm. 34
} 
praktek kebidanan baik yang berhubungan dengan kesejahteraan keluarga, masyarakat, teman sejawat, profesi dan dirinya. ${ }^{12}$

Berdasarkan latar belakang yang telah diuraikan, maka yang menjadi permasalahan adalah Bagaimana mekanisme pertanggungjawaban bidan atas terjadinya dugaan malpraktik dalam pelayanan kesehatan, bagaimana peran Majelis Pertimbangan Etik Bidan (MPEB) dan Majelis Pembelaan Anggota (MPA) / organisasi profesi bidan atas dugaan terjadinya pelanggaran hukum dalam manjalankan tugasnya sebagai pemberi pelayanan kesehatan dan bagaimana urgensi pengaturan profesi bidan dalam undang-undang dihubungkan dengan pertanggungjawaban bidan.

\section{Pembahasan.}

\section{a. Penyelenggaraan praktik kebidanan}

Penyelenggaraan praktik kebidanan di Indonesia mempunyai payung hukum yaitu didasarkan pada Undang-undang Nomor 36 tahun 2009 tentang Kesehatan serta peraturan Menteri Kesehatan. Dalam perundang-undangan tersebut disebutkan bahwa bidan termasuk bidang profesi yang terintegrasi dengan tenaga kesehatan. Pada Pasal 23 disebutkan bahwa tenaga kesehatan berwenang untuk menyelenggarakan pelayanan kesehatan. Penyelenggaraan kesehatan tersebut dapat dilakukan oleh orang yang mempunyai keahlian di bidangnya, hal ini dicantumkan pada ayat (2) yang berbunyi kewenangan untuk menyelenggarakan pelayanan kesehatan sebagaimana dimaksud pada ayat (1) dilakukan sesuai dengan bidang keahlian yang dimiliki. Untuk menyelenggaran pelayanan kesehatan tersebut,

\footnotetext{
${ }^{12}$ Sofyan, Mustika,dkk. 2007. Bidan Menyongsong Masa Depan. Jakarta: PP IBI. Hal.76
} 
tentu saja harus memiliki izin dari pemerintah dan selama memberikan pelayanan kesehatan tidka boleh mengutamakan kepentingan yang bernilai materi.

Ketentuan mengenai perizinan diatur dalam Peraturan Menteri kesehatan yaitu No 1464/MenKes/per/X/2010 tentang Praktik Kebidanan. Bidan yang menjalankan praktek pada sarana kesehatan atau dan perorangan harus memiliki SIPB dengan mengajukan permohonan kepada Kepala Dinas Kesehatan Kabupaten/Kota setempat, dengan melampirkan persyaratan yang meliputi :

a. Fotokopi SIB yang masih berlaku.

b. Fotokopi ijazah bidan.

Surat persetujuan atasan, bila dalam pelaksanaan masa bakti atau sebagai pegawai negeri atau pegawai pada sarana kesehatan.

a. Surat keterangan sehat dari dokter.

b. Rekomendasi dari organisasi profesi.

c. Pas foto $4 \times 6 \mathrm{~cm}$ sebanyak 2 lembar.

d. SIPB berlaku sepanjang SIB belum habis masa berlakunya dan dapat diperbaharui kembali.

Kemudian dalam Pasal 24 disebutkan bahwa tenaga kesehatan sebagaimana dimaksud dalam Pasal 23 harus memenuhi ketentuan kode etik, standar profesi, hak pengguna pelayanan kesehatan, standar pelayanan, dan standar prosedur operasional. Ketentuan mengenai kode etik dan standar profesi telah diatur oleh organisasi profesi. Kemudian ketentuan mengenai hak pengguna pelayanan kesehatan, standar pelayanan, dan standar prosedur operasional diatur dengan Peraturan Menteri. 
Walaupun tujuan pelayanan kesehatan tidak berorientasi pada keuntungan yang bersifat materi semata namun pada pasa Pasal 27 disebutkan tenaga kesehatan berhak mendapatkan imbalan dan pelindungan hukum dalam melaksanakan tugas sesuai dengan profesinya. Untuk meningkatkan kompetensi dari tenaga kesehatan khususnya bidan, maka dalam melaksanakan tugasnya berkewajiban mengembangkan dan meningkatkan pengetahuan dan keterampilan yang dimiliki.

Dalam pelayanan kebidanan, bidan sering dihadapkan pada masalah hukum yakni diduga adanya kelalaian dalam menjalankan profesinya yang berhubungan dengan pasien, sehingga apabila suatu waktu terdapat pengaduan pasien atas pelayanan kebidanan, maka pada Pasal 28 disebutkan untuk kepentingan hukum, tenaga kesehatan wajib melakukan pemeriksaan kesehatan atas permintaan penegak hukum dengan biaya ditanggung oleh negara. Pemeriksaan didasarkan pada kompetensi dan kewenangan sesuai dengan bidang keilmuan yang dimiliki. Pasal 29 Dalam hal tenaga kesehatan diduga melakukan kelalaian dalam menjalankan profesinya, kelalaian tersebut harus diselesaikan terlebih dahulu melalui mediasi.

\section{b. Bidan Sebagai Profesi}

Profesi adalah pekerjaan yang membutuhkan pelatihan dan penguasaan terhadap suatu pengetahuan khusus. Suatu profesi biasanya memiliki asosiasi profesi, kode etik, serta proses sertifikasi dan lisensi yang khusus untuk bidang profesi tersebut. Sebagai anggota profesi, bidan mempunyai ciri khas yang khusus. Sebagai pelayan profesional yang 
merupakan bagian integral dari pelayanan kesehatan. Bidan mempunyai tugas yang sangat unik, yaitu:

a. Selalu mengedepankan fungsi ibu sebagai pendidik bagi anak-anaknya.

b. Memiliki kode etik dengan serangkaian pengetahuan ilmiah yang didapat melalui proses pendidikan dan jenjang tertentu

c. Keberadaan bidan diakui memiliki organisasi profesi yang bertugas meningkatkan mutu pelayanan kepada masyarakat,

d. Anggotanya menerima jasa atas pelayanan yang dilakukan dengan tetap memegang teguh kode etik profesi.

Perilaku profesional bidan diantaranya adalah

a. Bertindak sesuai keahliannya

b. Mempunyai moral yang tinggi

c. Bersifat jujur

d. Tidak melakukan coba-coba

e. Tidak memberikan janji yang berlebihan

f. Mengembangkan kemitraan

g. Terampil berkomunikasi

h. Mengenal batas kemampuan

i. Mengadvokasi pilihan ibu

Setiap undang-undang selalu mengatur hak dan ewajiban, baik pemerintah maupun warga masyarakatnya, demikian dalam Undnag-Undang nomor 36 tahun 2009 tentang kesehatan. Hak dan kewajiban berdasarkan pasal 4 dan 5 UU kesehatan mengatakan bahwa: setiap orang mempunyai hak yang sama dalam memperoleh derajat kesehatan yang optimal, setiap 
orang berkewajiban ikut serta dalam pemeliharaan kes perorang, keluarga juga masyarakat.

\section{Kesimpulan.}

1. Kewenangan bidan melakukan pemberian suntikan oksitosin pada ibu bersalin normal di BPS dihubungan dengan kompetensi bidan.

Dasar kewenangan bidan sangat tegas dan kuat karena telah diatur oleh Undang-undang Nomor 36 Tahun 2009 Pasal 23, dan untuk pelaksanaan teknisnya telah didelegasikan melalui pasal 23 ayat (5) undang-undang tersebut kepada Peraturan Menteri Kesehatan (Permenkes) Nomor 1464/ Menkes/Per/X/2010 tentang Izin dan Penyelenggaran Praktik Bidan. Pemberian suntikan oksitosin pada ibu bersalin normal merupakan kewenangan bidan yang dilakukan setelah bayi lahir.

2. Pertanggungjawaban bidan dalam pemberian suntikan oksitosin pada ibu bersalin normal di BPS yang mengakibatkan perdarahan dihubungkan dengan Pasal 23 Undang-Undang Nomor 36 Tahun 2009 tentang Kesehatan Pemberian suntikan oksitosin pada ibu bersalin normal yang mengakibatkan perdarahan diakibatkan karena suntik oksitosin tersebut diberikan sebelum bayi lahir. Sehingga dengan demikian bidan melakukan kelalaian yang dapat mengakibatkan perdarahan pada ibu Postpartum. Hal ini telah melanggar Pasal 23 Undang-Undang Nomor 36 Tahun 2009 tentang Kesehatan karena melanggar prinsip pada Asuhan Persalinan Normal (APN) yaitu memberikan suntikan oksitosin yang diberikan sebelum kala II pada persalinan normal. Tanggung jawab bidan yaitu berupa sanksi perdata dan administrasi. Sanksi perdata atas tanggungjawab bidan dalam kasus tersebut adalah dengan 
memberikan ganti rugi kepada pasien baik secara materil maupun immateri dengan penerapan sanksi Pasal 1365 KUHPer yang menentukan bahwa tiap perbuatan melanggar hukum yang membawa kerugian kepada orang lain, mewajibkan orang yang karena salahnya mengganti kerugian tersebut. 


\section{DAFTAR PUSTAKA}

Depkes RI, 2012. Pencapaian Target Millenium Develompment Goal's (MDGs)

Depkes RI, 2012. Hasil Survei Demografi Kesehatan Indonesia 2012

Dinas Kesehatan Provinsi Jawa Barat. Analisis Penyebab Kematian Ibu tahun 2013.

Emmy Latifah, "Harmonisasi Kebijakan Pengentasan Kemiskinan di Indonesia Yang Berorientasi Pada Millennium Development Goals", Jurnal Dinamika Hukum, Vol. 11 No. 3

2011, Purwokerto: Fakultas Hukum Universitas Jenderal Soedirman, hlm. 403

Iswandari, Dini Hargianti. "Aspek Hukum Penyelenggaran Praktik Kedokteran: Suatu Tinjauan Berdasarkan Undang-Undang No.9/2004 Tentang Praktik Kedokteran". Jurnal Manajemen Pelayanan Kesehatan, Vol 09 No 2 Juni 2006. Universitas Gadjah Mada Pusat Manajemen Pelayanan Kesehatan

Gomella TL, Cunningham MD, Eyal FG, Zenk KE. Neonatology, Management, procedures, on call problems disease and drugs. New York : Lange Books/Mc Graw-Hill, 2004; 247-50

Hasil Wawancara dengan Pengurus IBI Kabupaten Ciamis. Pukul 10.30 WIB Hari Kamis, tanggal 9 Juli 2015

H. J. J. Lenan dan P. A. F. Lamintang. 1991. Pelayanan Kesehatan dan Hukum : suatu studi Tentang Hukum Kesehatan. Bandung: Rineka Cipta. HIm. 34

Saifuddin, 2012. Ilmu Kebidanan dan Kandungan. Yayasan Bina Pustaka Sarwono Prawirohardjo. Jakarta.

Sofyan, Mustika,dkk. 2007. Bidan Menyongsong Masa Depan. Jakarta: PP IBI. Hal.76

Tedi Sudrajat dan Agus Mardiyanto, "Hak Atas Pelayanan dan Perlindungan Kesehatan Ibu dan Anak (Implementasi Kebijakan di Kabupaten Banyumas)", Jurnal Dinamika Hukum, Vol. 12 No. 2 Mei 2012, Purwokerto: Fakultas Hukum Universitas Jenderal Soedirman, hlm. 261-262

Yanti dan W E Nurul, 2010, Etika Profesi Dan Hukum Kebidanan, Yogyakarta: Pustaka Rihama, hlm. 85

\section{PERATURAN PERUNDANG-UNDANGAN}

Keputusan Menteri Kesehatan Nomor 1464/Menkes/Per/X/2010 Tentang Izin Dan Penyelenggaraan Praktik Bidan

Peraturan Pemerintah No. 39/1995 Tentang Penelitian Pengembangan Kesehatan Undang-Undang Kesehatan No. 36/2009 Tentang Kesehatan 